\title{
Information decision-making support for periodic maintenance of gas balloon equipment
}

\author{
A. Evstifeev ${ }^{1^{*}}$ \\ ${ }^{1}$ National Research Nuclear University MEPhI (Moscow Engineering Physics Institute), Moscow, Russia \\ *evstifeev@mail.ru
}

\begin{abstract}
The issues of information support for decision-making during periodic maintenance of gas-cylinder equipment of vehicles running on natural gas, ensuring safe operation, contributing to an increase in the efficiency of transportation of goods and goods: reducing vehicle downtime due to failure of the fuel system using gas fuel by $10-18 \%$; reducing the likelihood of functioning of gas equipment in hazardous modes by $12-17 \%$. The technical requirements for gas equipment and procedures for its periodic maintenance are formulated. The concept of the formation and application of a unified state register of gas equipment, which is a tool for limiting admission to the turnover of products that does not meet regulatory and market requirements, is proposed. An information-logical model of decision-making support has been developed, which allows, depending on the current technical condition of assemblies and parts, based on the specified requirements for the duration of the period between maintenance, to propose the best option for carrying out diagnostic, repair and commissioning measures for gas-cylinder equipment of vehicles. The procedure for the formation of an extended list of measures for periodic maintenance of gas equipment is presented on the example of individual nodes of the fuel system of a vehicle running on compressed natural gas. The software implementation of the informationlogical model is carried out in the form of a plug-in extension to the database core of the decision support information system for the operation of gas equipment, implemented on the Oracle database management system with integrated support for the high-level objectoriented language Java. For the convenience of working with the information-logical model, a computational and analytical module of the information system for decision-making support during the operation of gas-cylinder equipment with elements of fuzzy logic has been developed. The model was tested on the example of the implementation of measures during the periodic maintenance of the gas equipment of the KamAZ 65116 truck.
\end{abstract}

Keywords: information support, making decisions, maintenance, natural gas equipment, fuzzy logic, information-logical model

For citation: Evstifeev A. Information decision-making support for periodic maintenance of gas balloon equipment. Prikladnaya informatika=Journal of Applied Informatics, 2022, vol.17, no.1, pp.19-26. DOI: 10.37791/2687-0649-2022-17-1-19-26 


\title{
Информационная поддержка принятия решений при проведении периодического технического обслуживания газобаллонного оборудования
}

\author{
A. A. Escmuфees ${ }^{1^{*}}$ \\ ${ }^{1}$ Национальный исследовательский ядерный университет «МИФИ», Москва, Россия \\ *evstipheev@mail.ru
}

Аннотация. Рассмотрены вопросы информационной поддержки принятия решений при проведении периодического технического обслуживания газобаллонного оборудования транспортных средств на природном газе, обеспечивающих безопасную эксплуатацию, способствующую повышению эффективности процессов транспортировки товаров и грузов: сокращению простоев транспортных средств по причине отказа топливной системы на газовом топливе на 10-18\%; снижению вероятности функционирования газобаллонного оборудования в опасных режимах на 12-17\%. Сформулированы технические требования, предъявляемые к газобаллонному оборудованию и процедурам его периодического технического обслуживания. Предложена концепция формирования и применения единого государственного реестра газобаллонного оборудования, являющегося инструментом ограничения допуска к обороту продукции, не соответствующей нормативным и конъюнктурным требованиям. Разработана информационно-логическая модель поддержки принятия решений, позволяющая в зависимости от текущего технического состояния узлов и деталей на основании заданных требований по продолжительности периода между техническим обслуживанием предложить оптимальный вариант проведения диагностических, ремонтных и наладочных мероприятий газобаллонного оборудования транспортных средств. Представлен порядок формирования расширенного перечня мероприятий периодического технического обслуживания газобаллонного оборудования на примере отдельных узлов топливной системы транспортного средства на компримированном природном газе. Программная реализация информационно-логической модели осуществлена в виде расширения к ядру базы данных информационной системы поддержки принятия решений при эксплуатации газобаллонного оборудования, реализованной на системе управления базами данных Oracle с интегрированной поддержкой объектноориентированного языка высокого уровня Java. Для удобства работы с информационнологической моделью разработан расчетно-аналитический модуль информационной системы поддержки принятия решений при эксплуатации газобаллонного оборудования с элементами нечеткой логики. Апробация модели выполнена на примере реализации мероприятий при проведении периодического технического обслуживания газобаллонного оборудования грузового автомобиля КамАЗ 65116.

Ключевые слова: информационная поддержка, принятие решений, техническое обслуживание, газобаллонное оборудование, нечеткая логика, информационно-логическая модель

Для цитирования: Евстифеев $A$. A. Information decision-making support for periodic maintenance of gas balloon equipment // Прикладная информатика. 2022. T. 17. № 1. С. 19-26. DOI:10.37791/2687-0649-202217-1-19-26 